\title{
AXIOLOGICAL APPROACH IN PEDAGOGY IN THE CONTEXT OF THE PROBLEMS OF SEMIOTICS OF CULTURE
}

\author{
Svetlana Valentinovna Gerasimova ${ }^{1}$ and Elena Vyacheslavovna Kulikova ${ }^{2}$ \\ ${ }^{1}$ Assoc. Prof., The Kosygin State University of Russia/Kosygin University, RUSSIAN \\ FEDERATION, metanoik@gmail.com \\ ${ }^{2}$ Assoc. Prof., The Kosygin State University of Russia/Kosygin University, RUSSIAN \\ FEDERATION, Elena@kulikova.pp.ru
}

\begin{abstract}
The purpose of the survey is to find out how modern students possess the basic values of culture. The article is written on the material of a survey in which first-year students of The Kosygin State University of Russia took part. The commandments remain the basic values of modern culture. They regulate interpersonal communications, form the basis of criminal law, and form the cultural contexts of art and literature. The survey was conducted in two phases. The purpose of the first phase of the survey is to find out whether students know the commandments and whether they have read the Bible.
\end{abstract}

The result of the survey: $43 \%$ of students can list some commandments, and $23 \%$ of students have read the commandments, but cannot list them.

Knowledge of the commandments varies from one social group to another. There is stratification even among the respondents. $33 \%$ of students replied they knew the commandments in one group, and $60 \%$ of students did the same in another one.

The survey found out not so much the real knowledge of the commandments, but the self-esteem of a person. Half of the students think of themselves as knowing the commandments. The following questions were formulated more specifically. They were asked to name associations to such images and stories from the Bible as Joseph the Beautiful, the parable of the Prodigal Son and the apostles Peter and Paul, offering to tell about them in as much detail as possible. The maximum percentage of knowledge relates to the parable of the Prodigal Son - 15\%. (Another $8 \%$ of students testified that they read this parable, but do not remember it) The commandments for memorizing are much more difficult than the parable of the Prodigal Son, so it is surprising that students know the commandments better than the parable. This percentage difference indicates that students rate themselves as knowing the commandments, although their ideas are very vague.

Modern society lives according to the commandments, although a little more than half of the students do not know the commandments, having only a general idea about them.

I $\mathrm{t}$ is obviously that that the novels by great Russian writers can be a source of students' ideas about goodness and evil. At the second phase of the survey the question was formulated as follows: "What authoritative texts have become a source of ideas about goodness and evil for you?» Next, it was listed: was it a favourite cartoon, movie or book? The movie text is also the text. In short, what was the main source of your knowledge about the commandments, until the moment of discussion in class?

The results of the second phase of the survey are as follows: $85 \%$ of respondents have heard the reputable sources that influenced their ideas about morality and the commandments from their parents and relatives, even though the emphasis was made on the novels and lyrics.

After pointing to the communicative source of ideas about good and evil, many students also indicated texts and film texts that preceded their knowledge of the commandments. The range of these texts is very wide. There are Disney cartoons, Nosov's stories, and Dostoevsky's novels here.

M.Yu. Lotman as the authoritative representative of the semiotics of culture in the Russian literary criticism 
defines culture as the sum of texts or as a sum of functions of these texts. We see that the main form of translation of the basics of culture is not texts, but communication.

It is impossible to put an equality sign between the knowledge of the commandments and moral behaviour. Modern culture, like a century ago, is based on the Biblical commandments. It is being modified, but its base remains the same. The semiotic system of modern culture is determined by the biblical dominants, but they are transmitted not through texts or even through the film texts, but through communication.

Modern education mainly involves memorizing texts, working with them. And modern youth mainly learns not what they have read, but what they have learned through communication. The maximum assimilation of the material is possible not through reading the text, but through the transformation of that had been read in the process of interpersonal communication. This principle applies not only to moral values, but also to intellectual ones. A modern person perceives culture not as a sum of texts, but as a sum of interpersonal communications that generate new communications. Students do not know what they have read, but what corresponds to the features of the modern cultural code, which is shifting from the field of book knowledge to the field of communicative experience.

The axiological approach in education is based on the tradition of A. S. Makarenko and K. D. Ushinsky. This tradition is developed by V. A. Slastenin and G. I. Chizhakova. The field of Axiology is of interest to many researchers nowadays. Modern education strives to go beyond the intellectual formation of the individual and become spiritually oriented. The axiological approach to education should be based on the achievements of the semiotics of culture, which studies the interaction of text and human behaviour in society. A text from a textbook should form not only the knowledge base, but also the cultural basis of the individual, which is possible only in the process of interpersonal communication.

Keywords: Axiology, Bible, semiotics of culture, communication.

\section{INTRODUCTION}

Education is a part of the semiotic system of modern culture and bears all its main features. The greatest value of modern culture is freedom of person's opinion and freedom of his/her action. But freedom should not contradict morality. Education strives to cultivate a free person. Tolerance and religious freedom are wonderful. These features of the education system are part of modern culture. Everything is great, but the education system, according to some experts, is in a State of crisis: "Dissatisfaction with modern education now covers the whole world. Orientation to knowledge, skills, abilities and competencies is able to serve any value aspirations. The crisis of education is most emphatically characterized by the following epithets: spiritless, abstract, ineffective, formal» (Timashkova, 2011, p. 134). The topic of the education crisis is still being discussed today. The Covid-19 education crisis is part of a more general education crisis related to axiological problems of modern education.

From a psychological point of view, it is natural to discuss not the crisis, but how to overcome it while the crisis lasts. Covid-19 has become a difficult test for the education system. Some students testify that information during distance learning makes less impression and is remembered worse.

Education is a homeomorphic part of the whole culture. M.Yu. Lotman explains that semantic (symbolic) type of culture is characterized by the fact that «a part is homeomorphic to the whole: it does not represent a fraction of the whole, but its symbol» (Lotman, 2002, p. 160). A part characterizes the whole, as a drop of seawater testifies to the whole sea. A part is a reduced model of the whole. Lotman testifies that this type of culture has a symbolic code.

The symbolic code has been preserved in the most important spheres of modern culture. We see this in the example of the education system. Hierarchy of values plays the same role in education as ideology in the State and in the whole semiotic system of culture. One may object that modern culture has a syntactic code. In modern culture the part does not reflect the whole. It would be perfect if one could give any examples when there is no strong ideology in the State, but there is a bright hierarchy of values in the education system of this State. It can be agreed that in a particular culture we hypothetically encounter a syntactic type of culture. However, most States have a symbolic code of culture in relation to education. If the State ideology has outlived itself, then the pedagogical axiology has also outlived itself. We can discuss it for a long time. But it will not come out of the crisis until the State ideology comes out of it's crisis. These are the laws of semiotics. 
The basis of modern culture was formed in the middle Ages. Then it began to be modified, but the base remained the same. From antiquity to the middle Ages there was a powerful cultural scrapping. The cultural code has changed. It has remained relevant for two thousand years. There is no new teaching that would displace the completely Christian code as the basis of modern culture. All new teachings enter the modern semiotic system of culture, changing it, but not affecting its cultural code.

The history of the twentieth century serves as an antidote to ideology. Ideology itself seems to be poison. Fascism and other totalitarian ideologies are examples of destructive ideologies that have caused the death of many people. The key question can be formulated as follows: is a constructive ideology possible?

If we believe that higher and secondary education needs a system of values, that it will not distort, but ennoble education, then we need to believe that the state ideology can be creative, uniting people. The task of the state is to develop such an ideology. Education will overcome the crisis when the state acquires a positive ideology.

Great Russian teachers built their pedagogical systems based on moral values. The analysis of the axiological concepts of the great Russian teachers is contained in the articles of many modern researchers. There are young researchers among them, such as S.S. Belousova (Belousova, 2017, pp. 579-584), and already established scientists, such as N.P. Yudina (Yudina, 2004, pp. 28-33). Axiological problems of modern education are considered in the works of scientists from The Kosygin State University of Russia (Kulikova E.V., Solyankin A.V. \& Yudin M.V., 2020, pp.170-175). The most important difference between classical pedagogical systems is that they were formed in the conditions of State ideology, and the hierarchy of values of modern pedagogy should be maintained in an atmosphere of its absence.

The purpose of this article is to analyze how and why hierarchies of values and modern axiological concepts exist in pedagogy in the absence of state ideology. There is an axiological component in modern pedagogy. Our task is to find out what provides its existence

The foundations of the axiological principles of education were laid by Konstantin Dmitrievich Ushinsky (1823-1870), Sergei Alexandrovich Rachinsky (1833-1902), Vasily Vasilyevich Zenkovsky (1881-1962), Ivan Alexandrovich Ilyin (1882-1954). Anton Semyonovich Makarenko (1888 - 1939). Vasily Alexandrovich Sukhomlinsky (1918-1970), Viktor Fedorovich Shatalov (1927-2020), Valentin Vasilyevich Kumarin (19282002), Evgeny Nikolaevich Ilyin (1929), Shalva Alexandrovich Amonashvili (1931), Evgeniya Vasilyevna Bondarevskaya (1931-2017) and others.

\section{MATERIALS AND METHODS}

The article is based on a survey of first-year students of the Kosygin Russian State University. The questioning was conducted among future linguistics and foreign languages teachers. These are creative and talented young people. The survey was conducted in two phases. The purpose of first phase the survey is to find out how modern students learned the commandments as the basic values of culture. The world is changing, but there are also immutable moral laws. They regulate interpersonal communication and legislation; also they form the value universe of works of literature and art.

As a result, it was clear that students behave according to the commandments even if they do not know them. Literature and art are the sources of moral law. So, at the second phase of the survey, the question was formulated as follows: what for you is an authoritative source of ideas about goodness and evil. Which book or movie taught you the commandments before they were discussed in class. The received data was analyzed and systematized.

The concepts of cultural semiotics were the methodological basis for the analysis of the obtained materials.

\section{RESULTS}

The result of the first phase of testing: $43 \%$ of students can list some commandments, and $23 \%$ of students have read the commandments, but cannot list them.

Knowledge of the commandments varies from one social group to another. There is stratification even among Kosygin university students. $33 \%$ of students replied they knew the commandments in one group, and $60 \%$ of students did the same in another.

This may be regarded as a good result, taking into consideration that the testing was conducted at the beginning of the first lecture and the residual knowledge was checked.

The survey revealed not the real knowledge of the commandments, but it shows the self-esteem of a person. 
Almost half of the students believe that they know the commandments. The questionnaire found that moral knowledge is highly valued among students, so that even partial knowledge is perceived as complete. Personality psychology notes that a person is prone to negative self-esteem; he/she may underestimate his/her abilities. The psychology of the collective indicates that a person perceives himself as a bearer of those values that are vital to the collective. For psychological stability, it is important for an individual student to be involved in the team, it is important to share the values that are quoted in it. I did not ask to list the commandments and reveal their meaning. We used to say that it is important to judge not by the letter of the law, but by the spirit of the law. Most of young people live according to the spirit of the moral law based on the commandments, so if young people do not remember the literal wording, they evaluate themselves as knowing and remembering. This knowledge is highly valued in society.

The following questions in the questionnaire were formulated more specifically. Literal knowledge was required. First th respondents were asked to indicate the associations with the image of Joseph the Beautiful. $2 \%$ of the students had real knowledge. The maximum percentage of knowledge relates to the parable of the Prodigal Son - 15\%. (Another $8 \%$ of students testified that they had read this parable, but did not remember it) $4 \%$ of students had real knowledge about the apostles Peter and Paul.

Modern youth lives morally and acts according to the commandments, even if they do not know them in the exact formulations that are in the Bible. At school, young people read novels by Russian classics. Russian writers of the XIX century created an artistic universe in which the characters live according to the commandments. The translation of cultural values takes place through literature. The writers knew the commandments and recorded them in novels, without speaking about them directly.

\section{In the absence of a state ideology, it is literature and art that assume its role. The semiotic system of Russian culture is based on biblical values and translates them.}

The main source of the hierarchy of values in modern pedagogy is culture. Culture changes more slowly than state ideology and politics, so culture preserves the spiritual values of past centuries and the best ideological attitudes of bygone eras.

Based on these ideas, the following question was formulated in the second phase of testing - "Which authoritative texts have become a source of ideas about goodness and evil for you?" Then the following points were listed: was it a favorite cartoon, movie or book? Ideas about goodness and evil are formed in very early childhood, so It was asked if the students' to pay attention to cartoons. The text of the film is also a text. In short, it was important for to realize what was the main source of knowledge about the commandments until the moment of our discussion?

The results of the second phase of the survey were not predictable. $85 \%$ of respondents listed authoritative sources that influenced their ideas about morality and commandments, with a mention of parents and relatives, despite the fact that the question was started on the texts of novels, poems, songs.

The importance of the role of parents was also noted by students at the first phase of the survey. When asked if students have read the Bible on their own, 30\% of students answered affirmatively. But $70 \%$ of the students gave an affirmative answer when were asked if their parents had read the children's Bible to them. $18 \%$ of students read the Gospel on their own, and $28 \%$ of students heard the Gospel reading from their parents and relatives. $14 \%$ of students mentioned that they studied the Bible in Sunday school. $12 \%$ of the students answered that they also learned the Gospel there.

Communication is an important source of knowledge about the commandments and about goodness and evil. Communication is valued by children more than cartoons and books. Only interpersonal communication becomes a source of lasting knowledge. Knowledge is formed not from the sources we have read, but from what we have used in communication after reading and what influenced the ways of communication. Sometimes a young person has read something but does not remember it. This means that this knowledge did not affect his/her communication and has not been activated.

After pointing to the communicative source of ideas about goodness and evil, many students also named books and films that could help them know the commandments. Students named cultural objects from Disney cartoons and Nosov's stories to Dostoevsky's novels as authoritative sources of ideas about goodness and evil.

The range of things mentioned by students is very wide and this material for the nest research.

\section{DISCUSSION}

M.Y. Lotman, as an authoritative representative of the semiotics of culture in Russian literary studies, defines 
culture as the sum of texts or as the sum of the functions of these texts. Our students are bright representatives of modern culture, but they are focused not on texts, but on communication. They value the culture of communication more than the culture of reading.

The semiotic system of modern culture is determined by biblical dominants, but they are transmitted not through texts or even through film texts, but through communication. This does not negate the great significance of M.Y. Lotman's research, but based on his semiotics of culture, the teacher builds the semiotics of communication.

The semiotics of communication is the modification and actualization of texts during communication.

Students retain some features of perception that were natural to them in childhood. And that's positive. This is not infantilism. This is the unchangeable nature of a human being. Children tend to express themselves not through words, but with actions, they need to act out their experiences in action. This feature of children's behavior is noted by many researchers. The intellectual development of a young person assumes that words and thoughts will play an increasingly important role in their life. A young man overcomes infantilism and expresses himself in words, but after speaking in words, in order to improve the knowledge he has received, he must apply knowledge in life, that is, use it in communication.

Kate Silverton said in her book: «Our children under five will often 'act out' their feelings because they don't always have the words to explain them just yet» (Silverton, 2021, p.12). She rightly notes that the child should go to the level of words, overcome the tendency to tantrums, because the child can say everything necessary not with crying, but with words.

Growing up doesn't change a person's nature. The significance of the action remains above the significance of the word. If a word from a book is not supported by action and communication, it can be forgotten: «What you read is worth not only discussing with preschoolers and younger schoolchildren, but also playing it. Theatricalization allows you to unobtrusively convey to them many things that are otherwise not assimilated or assimilated with great difficulty» (Shishkova, 2006, p. 513).

It is important to take into account this fundamental personality trait in pedagogy. The training should include an element of interpersonal communication and play, especially if we want to give an idea of eternal moral values. The main value of a teacher is the personality of a student or a student: «lt's a miracle that everyone is different from everyone. Individuality has an ideal value character and is understood as a set of semantic relations and attitudes of a person in the world, which are assigned in the course of life in society, provide orientation in the hierarchy of values and mastery of behavior in the situation of motives» (Maslov S.I., Maslova T.A., 2013, p. 206). A.F. Losev, reflecting on the myth, also comes to the conclusion that personality is a mystery.

The personality is in the world of standard objects. We all live in a common universe. It is not external influences that make a child a person, for they are the same for all ages, but the semantic relations of a person to them. The personality itself is a semiotic system. Personality is a homeomorphic part of a great culture.

\section{CONCLUSION}

Modern education mainly involves memorizing texts, working with them. The role of the text increased dramatically during self-isolation in the days of Covid-19. Instead of a live explanation of the subject, the student was initially assigned to read some texts. But the assimilation of cultural and moral values and commandments does not occur at the moment of reading and memorizing, but at the moment of their creative use in the process of communication or play. A person has a powerful creative potential, which is used in the game and communication. If new knowledge is not based on creative communication, then it is easily forgotten. This principle applies not only to moral values, but also to intellectual ones. A modern person perceives culture not as a set of texts, but as a set of interpersonal communications that generate new communications. Personality is a part, homeomorphic to the whole of culture. A person lives in a cultural cosmos and creatively assimilates the values of culture. Only the creative game communication of a person with the semiotic system of culture puts a person in his proper place in this system. The child is not a slave of culture, who is forced to assimilate the golden reserve of its values, but a creative personality in which the semiotic system of culture begins an independent original life, transforming in the process of creativity, play and communication.

The axiological approach in education should be based on the achievements of the semiotics of culture, which studies the interaction of text and human behavior in society. A person can be compared to a revived text, but when a text or the entire system of cultural texts comes to life in a person in the process of gaining 
life experience and communication, it is modified, since it enters as part of the semiotic system of human consciousness and personality is part of the semiotic system of culture. Sometimes the personality turns out to be larger than the whole culture, because he/she includes the whole culture through significant parts that are homeomorphic to it and gave him a unique personal interpretation.

\section{REFERENCE LIST}

Belousova S.S. (2017) Questions of axiology in Russian pedagogy. Theoretical and practical aspects of scientific research. Materials of the International (correspondence) scientific and practical conference.

Kulikova E.V., Solyankin A.V. \& Yudin M.V. (2020) Implementation of the axiological approach in educational work and foreign language teaching. In E.V. Kulikov (ed). Materials of the international scientificpractical conference «Actual problems of linguistics and intercultural communication». (pp. 170-175). Russia. Moscow: Federal State Budgetary Educational Institution of Higher Education «The Kosygin State University of Russia (Technology. Design. Art)»

Losev A.F. (2001) Dialectics of Myth. Russia. Moscow: publishing house «Mysl».

Lotman Yu.M. (2002) Articles on the semiotics of culture. Russia, St. Petersburg: Humanitarian Agency "Academic Project".

Maslov S.I., Maslova T.A. (2013). Axiological approach in pedagogy. Bulletin of the Tula State University. Humanitarian sciences. https://cyberleninka.ru/article/n/aksiologicheskiy-podhod-v-pedagogike

Silverton Kate (2021) There's no such thing as 'naughty'. The groundbreaking guide for parents with children aged 0-5. London, Great Britain: Piatkus

Timashkova Lecture 7. Axiological approach in the study of pedagogical phenomena// Tsyrkun I.I., Artemenok E.N. and Borisevich A.R. Pedagogy of the modern school: fundamentals of pedagogy. Didactics. In I.I.Tsyrkun (ed) Minsk.

Yudina N.P. (2004) Domestic pedagogy of the turn of the XIX-XX centuries through the prism of the humanistic tradition: statics and dynamics. Bulletin of Orenburg State University. 12 (37). 